\title{
Frédéric Chopin og hans lidelse
}

\author{
Sammendrag \\ Bakgrunn. I 2010 feiret vi 200-årsjubi- \\ leum for Frédéric Chopins fødsel. \\ Han etterlot seg over 230 fantastiske \\ verker, ofte beskrevet som romantiske, \\ følelsesladede og poetiske. Chopin \\ komponerte nesten utelukkende for \\ piano solo og er kalt pianistenes kom- \\ ponist. Fra tenårene var han plaget \\ med luftveisinfeksjoner, etter hvert \\ også med hemoptyse, store respira- \\ toriske problemer, diaré og vekttap. \\ Deler av sitt voksne liv opplevde han \\ som en stor lidelse. Han døde 39 år \\ gammel. Antatt dødsårsak var tuber- \\ kulose, men de siste årene har det vært \\ foreslått andre mulige differensial- \\ diagnoser
}

Materiale og metode. For å forfølge de ulike diagnostiske alternativer ble ikke-systematiske litteratursøk gjennomført i PubMed, Embase, Current Contents, Google og relevante oppslagsverk.

Resultater. Den offisielle dødsårsaken er tuberkulose, men obduksjonsrapporten er aldri funnet. Både cystisk fibrose og $\alpha_{1}$-antitrypsinmangel er aktuelle differensialdiagnoser som kan forklare hans symptomer.

Fortolkning. Til tross for en invalidiserende sykdom var Chopin musikalsk kreativ helt til det siste. Hans lidelse må ha påvirket det musikalske uttrykket, som er preget av intimitet og sentimentalitet. Det er lite trolig at vi noensinne vil finne en definitiv dødsårsak.

\author{
Ulf E. Kongsgaard \\ ulf.kongsgaard@medisin.uio.no \\ Avdeling for forskning og utvikling \\ Akuttklinikken \\ Oslo universitetssykehus \\ Postboks 4956 Nydalen \\ 0424 Oslo \\ og \\ Det medisinske fakultet \\ Universitetet i Oslo
}

I 2010 var det 200 år siden Chopin ble født. Frédéric François Chopin, døpt Fryderyk Franciszek Chopin, ble født i Żelazowa Wola, en liten landsby utenfor Warszawa. Fødselsdatoen er ikke entydig fastslått. Det er funnet en dåpsattest som oppgir 22. februar $1810(1,2)$, men Chopin selv oppga alltid fødselsdagen 1. mars. Han døde 17. oktober 1849 i Paris, 39 år gammel.

Chopins musikalske talent viste seg tidlig. Han ble regnet som vidunderbarn og komponerte allerede i en alder av sju år $(3,4)$. De første polonesene i B-dur og g-moll er datert 1817 og viser en uvanlig begavelse for improvisasjon. Fra 1822 fikk han privatundervisning i musikkteori og komposisjon. Han tok middelskoleeksamen i 1826 og studerte deretter ved konservatoriet, først kontrapunkt, så musikkteori, generalbass og komposisjon $(3,5)$. Han fulgte også forelesninger ved universitetet.

20 år gammel forlot Chopin Warszawa og reiste til Wien. Kort tid etter brøt den polske novemberoppstanden ut. Den påfølgende undertrykkelsen fra Russland gjorde at det var vanskelig å reise tilbake til Warszawa, selv om han lengtet hjem og ønsket å støtte opprøret $(1,3,6)$. Faren advarte ham mot å reise tilbake og mente han bedre kunne tjene fedrelandet med sin kunst enn med gevær $(2,3,5)$. Dratt mellom bekymring for familien og en drøm om berømmelse innen musikken valgte han å reise til Paris, der han levde størstedelen av livet.

I Paris fant han et kreativt miljø og fikk en omgangskrets som inkluderte mange av samtidens mest kjente forfattere og komponister (5). Han klarte seg godt sosialt og økonomisk og ernærte seg som pianolærer, komponist og konsertpianist $(5,7)$ Selv om han var en stor Polen-patriot $(2,3)$, brukte han den franske versjonen av sitt navn, som han er mest kjent under.

Chopin er en av de mest innflytelsesrike og populære klaverkomponistene fra 1800- tallet. I Polen anses han som den som har betydd mest for landets musikkhistorie $(3,7)$. Han skrev nesten utelukkende for piano solo og er kalt pianistenes komponist. Selv var han en virtuos pianist som gjennom sin musikk først og fremst uttrykte poesi, følelse, dybde og nyanser. Over 230 av hans verker er bevart, kun noen manuskripter og stykker fra tidlig barndom er tapt. Totalt ble det rundt 80 opusnumre. Pianoet opptrer $i$ alle, og de aller fleste stykkene er for piano solo. Til tross for dårlig helse og et kort liv etterlot han seg bl.a. 27 etyder, 26 preludier, 21 nokturner, 58 masurkaer, 17 poloneser, 19 valser, fire impromptuer, to konserter, fire ballader, fire scherzoer og tre sonater samt flere andre stykker (7).

Flere andre kjente komponister, som Wolfgang Amadeus Mozart (1756-91), Franz Schubert (1797-1828) og Felix Mendelssohn (1809-47), rakk heller ikke å fylle 40 år. Disse døde imidlertid ganske plutselig og uventet, mens Chopin var ved dårlig helse det meste av sitt voksne liv (fig 1).

\section{Familiens sykehistorie}

Chopins far var en del plaget av luftveisinfeksjoner, men levde til en alder av 73 år. Hans mor var angivelig ved god helse og ble 77 år gammel $(6,8,9)$. Chopin hadde tre søstre. Isabella døde 70 år gammel. Ludwika var mye plaget av luftveisinfeksjoner og døde angivelig av en lungesykdom 47 år gammel. Emilia var et vevert barn med skrøpelig helse. Hun led av residiverende luftveisinfeksjoner, dyspné, vekttap og hematemese og døde etter en massiv øvre gastrointestinal blødning bare 14 år gammel $(5,6,9)$.

\section{Chopins kroniske plager}

I tenårene var Chopin stadig plaget av respiratoriske problemer, diaré og vekttap

\section{Hovedbudskap}

- Chopin var store deler av sitt liv plaget med luftveisinfeksjon, hemoptyse, store respiratoriske problemer, diaré og vekttap

- Man har ment at han døde av tuberkulose, 39 år gammel

- Det har de siste årene vært foreslått differensialdiagnoser som cystisk fibrose og $\alpha_{1}$-antitrypsinmangel 


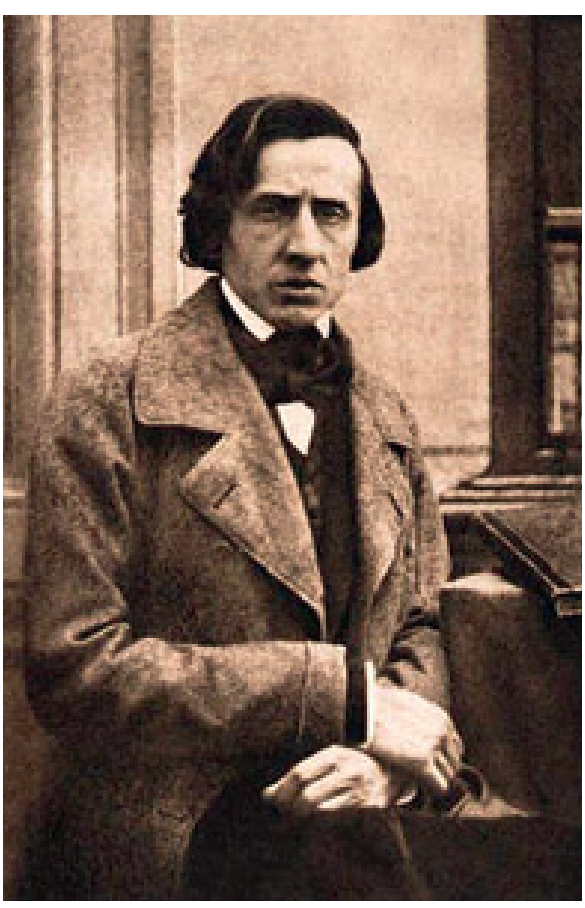

Figur 1 Det eneste kjente fotografiav Chopin, 38 år gammel

(6). I 1826, 16 år gammel, var han syk i en periode på seks måneder, med symptomer som hoste, hodepine og cervikal lymfeglandelsvulst $(3,6)$. Han hadde tilsvarende plager mens han bodde i Wien som 20-åring $(10,11)$. Fra perioden 1831-35 er det beskrevet mange episoder med bronkitt og laryngitt. Han utviklet aldri skikkelig skjeggvekst, og til tross for at man mener han hadde seksuelt forhold til flere kvinner, fikk han aldri barn $(11,12)$.

Under en influensaepidemi i Paris i 1837 ble Chopin rammet av høy feber, hemoptyse og hematemese. Hans lege, dr. PaulLéon-Marie Gaubert (1805-66), mente han ikke led av tuberkulose og anbefalte ham et varmere klima (6). Det er spekulert i hvorvidt denne legen virkelig mente at han ikke led av tuberkulose, eller om han valgte en annen diagnose pga. mulig stigmatisering av pasienter med denne sykdommen (6). Chopin var konstant plaget av dyspné og ble lett utslitt. Ofte måtte han bæres i seng etter å ha spilt klaver lenge.

I 1836 møtte han forfatteren Aurore Dudevant (1804-76), bedre kjent som George Sand. I november 1838 dro han sammen med henne og hennes to barn til Mallorca for å unnslippe vinteren $(3,6,8)$. Dette var ingen vellykket reise med hensyn til hans helse. I Valldemossa (fig 2) var han stadig plaget med feber, konstant hoste og diaré. Til tross for dette var han produktiv. De 24 preludiene, op. 28, fikk blant annet sin endelige form under oppholdet på Mallorca. Legene han konsulterte der, mente han hadde tuberkulose $(8,10)$. Dette resulterte $\mathrm{i}$ at lokalbefolkningen unngikk ham av frykt for smitte. George Sand måtte betale for brenning av møblene da de forlot Valldemossa $(3,6,8)$. I februar 1839 dro de tilbake til fastlandet og tilbrakte en tid på
George Sands landsted Nohant, men flyttet tilbake til Paris i løpet av høsten. Fra 1840 Chopins ble helsetilstand forverret. Han fikk ytterligere vekttap (veide bare 45 kilo) og ble beskrevet som blek, tynn og sykelig av utseende (6). En karikatur tegnet av en venninne i 1844 viser tydelig at han har utviklet tønnethorax $(6,13)$.

Chopin hadde flere perioder med depresjoner (3). Han ga uttrykk for desperasjon, håpløshet, apati og søvnløshet under oppholdet i Wien i 1830-31 (3), sannsynligvis som en reaksjon på opprøret i Polen og hans kvaler med hensyn til å flytte til Frankrike. Senere i livet synes depresjonene å stå i sammenheng med eksaserbasjoner av sykdommen (3). Man kan derfor spekulere i om hans mentale helse var et uttrykk for en følgetilstand til en progredierende kronisk sykdom med store plager heller enn en primær psykisk lidelse.

\section{De siste årene}

Vinteren 1847 opplevde han en bedre periode. Selv om han fremdeles var kortpustet og slapp, var han bestemt på å reise til London $(2,4)$. Der hadde han håpet å gi en serie med konserter, men ble sengeliggende store deler av tiden. I april 1848 følte han seg imidlertid frisk nok til å reise til Skottland etter invitasjon fra Jane Stirling (1804-59). Hun var en tidligere elev som hadde tatt seg av Chopin etter bruddet med George Sand. Til tross for at han klarte å gjennomføre konserter i Edinburgh,

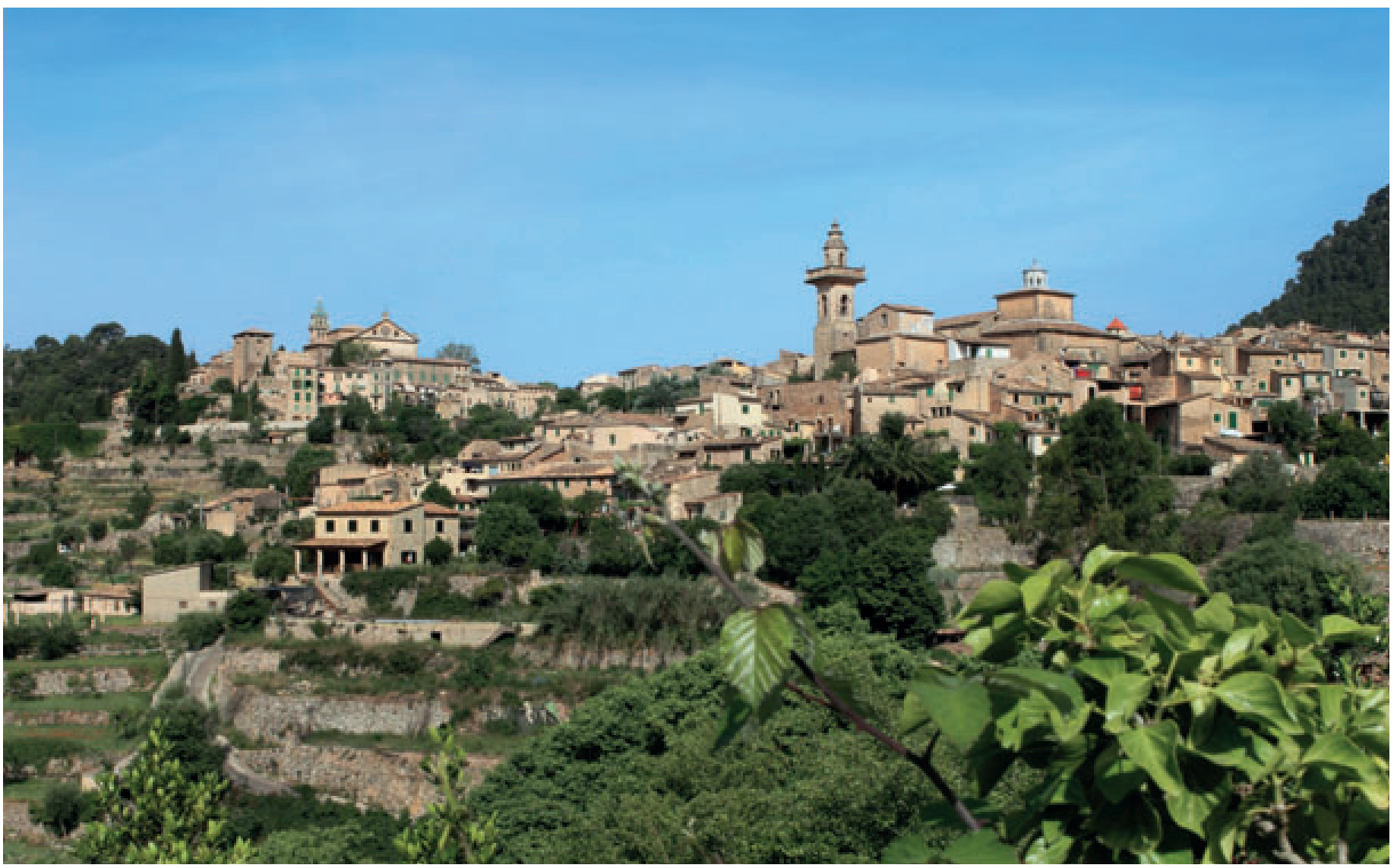

Figur 2 Landsbyen Valldemossa på Mallorca, der Frédéric Chopin og George Sand tilbrakte vinteren 1838-39. Foto Istockphoto 
Manchester og Glasgow, var han for det meste så utmattet at han måtte bæres opp til sitt soverom $(3,6)$. Tilbake i London ble han igjen sengeliggende med feber, hoste og kvelningsfornemmelser. Han bestemte seg derfor for å reise tilbake til Paris 19. november.

Tilstanden forverret seg nå raskt. I tillegg til hoste, dyspné og svingende feber var han plaget av smerter i håndledd og ankler, hemoptyse, hematemese og ankelødemer $(3,6,10)$. Flere leger ble konsultert og ga ulike vurderinger og råd. Dog var de enige om at han var for syk til å kunne flytte fra Paris $(6,10)$.

\section{De siste dagene}

I begynnelsen av oktober 1849 forverret situasjonen seg ytterligere. Chopin var ikke lenger i stand til å sitte oppreist, og han var så svak at han snakket med hviskestemme (11). I perioder ble han oppfattet som bevisstløs. Han fikk besøk av søsteren Ludwika, og til henne ga han uttrykk for ønsket om at hjertet skulle fraktes til Warszawa etter hans død og at Mozarts Requiem i d-moll skulle oppføres i begravelsen $(4,7)$. Han døde klokken 2 om morgenen 17. oktober 1849 etter å ha vært bevisstløs et døgn. Samme dag laget Jean Baptiste Auguste Clésinger (1814-83) dødsmasken (fig 3) og en gipsavstøpning av hendene $(3,6)$. I dødsattesten er skrevet diagnosen tuberkulose i lunger og larynx (6).

Begravelsen fant sted tirsdag 2. november i Madeleine-kirken. Siden Chopin hadde ønsket seg Mozarts dødsmesse, var den blitt utsatt i to uker. Årsaken var at det i denne kirken ikke var tillatt med kvinnelige sangere (i tillegg til korstemmene er det solopartier for alt og sopran). Man ga til slutt etter, på betingelse av at de kvinnelige sangerne sto bak et forheng $(2,7,14)$. Også Chopins egne preludier nr. 4 i e-moll og nr. 6 i h-moll ble spilt. Frédéric Chopin hviler på Père-Lachaisekirkegården i Paris. Hans hjerte ble, etter hans ønske, fraktet til Polen og plassert i en urne i Helligkorskirken i Warszawa.

\section{Obduksjon}

Obduksjonen ble utført av dr. Jean Cruveilhier (1791-1874) $(6,15)$. Han ble regnet som en av tidens ledende medisinere og var professor i kirurgi, anatomi og patologi (16). Han skrev flere bøker om tuberkulose (16). Obduksjonsrapporten er aldri funnet. Ifølge Jane Stirling, i korrespondanse med Franz Liszt, hadde professor Cruveilhier uttalt at «obduksjonen ga ikke svar på dødsårsaken, men lungene var mindre affisert enn hjertet. Det er en sykdom jeg ikke tidligere har sett» $(8,17)$.

\section{Differensialdiagnoser Tuberkulose}

Tuberkulosen har eksistert i flere tusen år. Utbredelsen av sykdommen nådde en topp på 1700- og 1800-tallet $(8,18)$. Sannsynligvis hadde nærmere halvparten av den engelske befolkningen en eller annen form for aktiv tuberkulose i første halvdel av det 19. århundre (8). Den første moderne kliniske beskrivelse av sykdommen ble publisert i 1810 (18). Tuberkelbasillen ble første gang påvist i 1882 .

Behandlingen av lungetuberkulose på 1800-tallet besto av hvile, god ernæring og styrking av kroppens egne forsvarsmekanismer (18). Det foregikk vanligvis på egne sanatorier som samtidig virket som isolasjonsinstitusjoner for smitteførende personer. Dette var altså en utbredt sykdom på den tiden Chopin levde. Han kunne vært smittet i ungdomsårene av sin søster Emilia. Hun døde muligens av tuberkulose, men det forklarer ikke like godt hennes gastrointestinale blødninger. Hadde Emilia vært rammet av miliær tuberkulose eller direkte progrediering av en primær lesjon, ville symptomene sannsynligvis vært mer dramatiske, gitt hennes svært unge alder (15). Ingen av de andre familiemedlemmene hadde imidlertid tydelige tegn på tuberkulose (15).

Chopins hemoptyse kan forklares av sykdommen, men mangel på trommestikkfingre og hans hematemese og diaré peker $i$ retning av en annen diagnose. Selv om Cruveilhiers obduksjonsrapport aldri er funnet, tyder annenhåndsrapporter på at han var overbevist om at Chopin led av en annen sykdom $(8,10,17)$. Om komponisten skulle hatt tuberkulose, er det påfallende at han ikke smittet de nærmeste i omgivelsene - som George Sand og hennes to barn - $\mathrm{i}$ løpet av lang eksponeringstid (8).

\section{Cystisk fibrose}

Cystisk fibrose er en medfødt arvelig sykdom med forstyrrelser i kjertelfunksjonen i flere organer, blant annet lungene, mage-tarm-kanalen og bukspyttkjertelen (19). De rammede har unormalt luftveissekret og svekket lokalt slimhinneforsvar i luftveiene. Dette disponerer for kolonisering og infeksjon med ulike mikrober som sjelden gir sykdom hos friske personer. De fleste trenger hyppig og langvarig antibiotikabehandling mot bakterielle infeksjoner og kolonisering i luftveiene.

Cystisk fibrose er den vanligst forekommende autosomalt recessivt arvelige sykdommen vi kjenner (19). I tiden før antibiotika var det sjelden pasientene nådde 30 år. Imidlertid finnes det varierende alvorlighet av denne sykdommen, og man kan ikke utelukke at Chopin hadde en mild form (12). Tilstanden er assosiert med residiverende pneumonier, pancreassvikt, levercirrhose og infertilitet. Dette passer også både med Chopins barnløshet og med hans diaré, kanskje forårsaket av pancreasinsuffisiens med fettintoleranse og steatoré (8). $\alpha_{1}$-antitrypsinmangel ( $\left.\alpha_{1} A T\right)$

Dette er en kodominant arvelig sykdom der $\alpha$-antitrypsinnivået i blodet er for lavt. Det finnes ulike genetiske varianter, men av dem som utvikler sykdom, har $95 \%$ mangel på det som betegnes Z-genet (eller Z-allelet) $(9,13)$. Noen genetiske varianter disponerer først og fremst for leversykdom, andre for lungesykdom og noen for begge deler $(9,20)$. Symptomer på $\alpha_{1}$-antitrypsinmangel inkluderer dyspné, residiverende luftveisinfeksjoner eller obstruktiv astma med dårlig respons på vanlig behandling. De rammede kan utvikle lungeemfysem i 30-40-årsalderen. Sykdommen kan også føre til nedsatt leverfunksjon hos enkelte, og leverlesjoner er svært vanlig. En del pasienter utvikler cirrhose og leversvikt (6). $\alpha_{1}$-antitrypsinmangel kunne forklare Emilies død som 14-åring av hematemese kanskje forårsaket av oesophagusvaricer pga. portal hypertensjon (9). Riktignok ville man kanskje samtidig ha forventet icterus eller ascites, men disse symptomene er ikke beskrevet $(8,9) . \alpha_{1}$-antitrypsinmangel vil kunne forklare Chopins residiverende lungeinfeksjoner, vekttap og gastrointestinale symptomer. Disse plagene var kroniske gjennom hele hans voksne liv.

\section{Diagnoser og patografier}

Det er tenkelig at Chopin led av samme sykdom som søsteren Emilia, og det er sannsynlig at hans leger ikke hadde sikre kunnskaper om hva slags sykdom det dreide seg om. I flere artikler er de ulike differensialdiagnosene diskutert (3, 6, 21-23), og det er i dag ingen absolutt konsensus om hva han døde av.

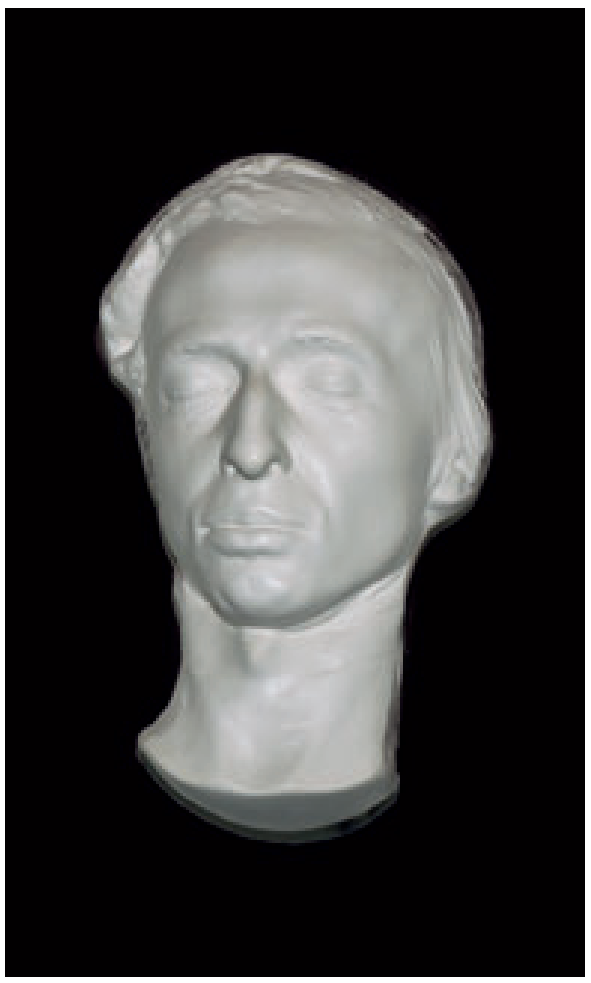

Figur 3 Chopins dødsmaske 
Artikler som omhandler sykdom hos avdøde, berømte personer kalles ofte patografier $(24,25)$. En patografi kan være skrevet som et vitnesbyrd om sykdommen, nærmest som en reiseskildring som beskriver forfatterens opplevelser $i$ et nytt og uvant landskap (25). Differensialdiagnosene kan være interessante, men er ofte spekulative og vurdert på bakgrunn av observasjoner gjort av andre i ikke-medisinsk sammenheng. Dette betyr at det er helt umulig å teste en hypotese om hvilken sykdom det egentlig dreide seg om.

I Chopins tilfelle har vi imidlertid organisk materiale som teoretisk sett kan testes opp mot noen av de aktuelle differensialdiagnoser. Chopins hjerte finnes i dag i en krystallurne fylt med alkohol, brakt tilbake fra Paris av hans eldre søster Ludwika i 1849 og oppbevart i Helligkorskirken i Warszawa. Med dagens genteknologi ville det kanskje være mulig å undersøke hvorvidt han led av cystisk fibrose eller $\alpha_{1}$-antitrypsinmangel. Dr. Michal Witt fra instituttet for molekylær- og cellebiologi i Warszawa har søkt om få utføre genetiske tester på Chopins hjerte (12). En talskvinne fra det polske kulturministeriet, Iwona Radziszewska, fortalte imidlertid 21. juli 2008 at det var bestemt at det ikke ville bli gitt tillatelse til å gjøre slike tester (26).

\section{Konklusjon}

Til tross for en invalidiserende sykdom var Chopin musikalsk kreativ også i perioder med symptomforverring. Sannsynligvis vil vi aldri avdekke dødsårsaken. De mest sannsynlige differensialdiagnoser er tuberkulose, cystisk fibrose eller $\alpha_{1}$-antitrypsinmangel. Er det viktig å vite hva Chopin døde av for å kunne nyte hans musikk? Selvfølgelig ikke!

Mange komponister beundret og fant inspirasjon i Chopins musikk $(3,27)$. Vi andre kan også la oss inspirere av en komponist og virtuos pianist som på tross av betydelig sykdom og lidelse gjennom det meste av sitt korte liv var så arbeidsom og produserte så fantastiske pianostykker. På den annen side er det i medisinsk sammenheng interessant å spekulere i hvordan så mange års lidelse kan ha påvirket Chopin som komponist og utøvende kunstner.

Han var ingen pianist for de store konsertsaler og foretrakk små salonger $(27,28)$. Hans anslag kunne mangle kraft (10), og han hadde en forkjærlighet for korte komposisjoner $(7,11,28)$. Dette kan ha hatt sammenheng med hans fysiske begrensning, men kan selvfølgelig også være uttrykk for en bevisst pianoteknikk og musikalsk uttrykk. Depresjonene kan ha kommet sekundært til eksaserbasjon av sykdommen, men en primær psykisk lidelse kan heller ikke utelukkes $(3,11)$. Det er likevel påfallende at hans mest kreative periode er årene mellom 1839 og 1846, en periode der tilstanden ble forverret (3). Som konklusjon er det rimelig å anta at Chopins lidelse må ha påvirket det musikalske uttrykket, som er preget av intimitet, melankoli og sentimentalitet (7).

\section{Oppgitte interessekonflikter: Ingen}

\section{Litteratur}

1. Niecks F. Frédérick Chopin: as man and a musician. London: Novello, Ewer \& Co, 1890

2. Siepmann J. Chopin. The reluctant romantic. London: Victor Gollancz, 1995

3. Neumayr A. Music and medicine: Chopin Smetana, Tchaikovsky, Mahler. Notes on their lives, works and medical history. Bloomington: Medi-Ed Press, 1997.

4. Marek GR, Gordon-Smith M. Chopin. London: Weidenfeld and Nicolson, 1979

5. Szulc T. Chopin in Paris. The life and times of the romantic composer. New York: Scribner, 1998.

6. Kubba AK, Young M. The long suffering of Frederic Chopin. Chest 1998; 113: 210-6.

7. Sadie S, Tyrell J. Chopin. The New Grove Dictionary of music and musicians. 2. utg. Bd. 5. New York: Oxford University Press, 2001: 706-36.

8. Eriksson S. Led Chopin av antitrypsinbrist? Läkartidningen 2003; 100: 2449-54.
9. Reuben A. Chopin's serpin. Hepatology 2003; 37: 485-8.

10. O'Shea JG. Was Frédéric Chopin's illness actually cysticfibrosis? Med J Aust 1987: 147: 586-9.

11. O'Shea J. Music and medicine. Medical profiles of great composers. London: Dent, 1990.

12. Majka L, Goździk J, Witt M. Cystic fibrosis - a probable cause of Frédéric Chopin's suffering and death. J Appl Genet 2003; 44: 77-84.

13. Erlinger S. Frederic Chopin and Michael Jackson what could they have in common? Gastroenterol Clin Biol 2010; 34: 246-9.

14. Eisler B. Chopin's funeral. Toronto: Random House, 2003.

15. Kuzemko JA Chopin's illnesses. J R Soc Med 1994; 87: 769-72

16. Androutsos G, Vladimiros L. The eminent French pathologist Jean Cruveilhier (1791-1874) and his works on cancer. J BUON 2006: 11:369-76.

17. Hedley A. Selected correspondence of Chopin. London: Heinemann, 1962

18. Chaisson RE, Nachega J. Tuberculosis. I: Warrel DA, Cox TM, Firth JD et al, red. Oxford Textbook of Medicine. 4. utg. Oxford: Oxford University Press. 2003: $556-72$.

19. Geddes D, Bush A. Cystic fibrosis. I: Warel DA, Cox TM, Firth JD et al, red. Oxford Textbook of Medicine. 4. utg. Oxford: Oxford University Press, 2003 1428-38

20. Fagerhol MK, Laurell CB. The Pi system-inherited variants of serum alpha 1-antitrypsin. Prog Med Genet 1970; 7: 96-111.

21. Carter ER. Chopin's malady. Chest 1998: 114 $655-6$.

22. Cheng TO. Chopin's illness revisited. Chest 1998; 114: 1796.

23. Margolis ML. The long suffering of Frederic Chopin, revisited. Chest 1998: 114: 655

24. Karenberg A. Retrospective diagnosis: use and abuse in medical historiography. Prague Med Rep 2009: 110: 140-5.

25. Holmøy T, Frich JC. Beretninger fra livet med amyotrofisk lateral sklerose. Tidsskr Nor Lægeforen 2006; 126: 3297-9

26. McKie R. Row over plan to DNA test Chopin's heart. The Observer 27.7.2008. www.guardian.co.uk/music/2008/jul/27/ classicalmusicandopera.genetics (5.1.2011)

27. Schonberg H. Apotheosis of the piano. Frederic Chopin. 3. utg. New York: W.W. Norton \& Company, 1970

28. Martens JS. Chopin. En biografi. Oslo: Høvik Bokhandel, 1945

Mottatt 1.10. 2010, første revisjon innsendt 13.1. 2011, godkjent 27.1. 2011. Medisinsk redaktør Are Brean. 